\title{
Corporate Social Responsibility and Internationalization of Czech Transport Enterprises
}

\author{
Emil VELINOV ${ }^{1},{ }^{2 *}$ and Simona CINCALOVA ${ }^{3}$ \\ 1 SKODA AUTO University, Mlada Boleslav, Czech Republic; emil.velinov@savs.cz \\ 2 RISEBA University of Applied Sciences, Riga, Latvia; emil.velinov@riseba.lv \\ 3 College of Polytechnics Jihlava, Czech Republic; simona.cincalova@vspj.cz \\ * Corresponding author: emil.velinov@savs.cz
}

\begin{abstract}
The paper aims at investigating the conditions for development and application of Corporate Social Responsibility best practices in selected Czech transport small and mediumsized enterprises. Furthermore, the study sheds a light on the internationalization process, which is taking place in seventy Czech transport companies by exploring the importance of corporate social responsibility pillars in three regions in Bohemia. Furthermore, the paper is focusing on the applicability and transferability of such of corporate social responsibility and internationalization measures, which will support the Czech transport companies to become more competitive entities by adopting or improving such practices. Paper's results show that the firms, which tend to internationalize more than their counterparts, tend to implement more corporate social responsibility activities. The study suggests that the selected firms from the transport sector are acting proactively by adopting best practices on corporate social responsibility in order to attract more investor and to foster their process of internationalization.
\end{abstract}

Keywords: corporate social responsibility; internationalization; transport

\section{JEL Classification: M14; O18}

\section{Introduction}

The global business highly is acknowledged with the fact that international trade has a big impact on society. Wide variety of stakeholders across businesses suggests that customers are getting more and more demanding. Furthermore, there are challenges and risks connected with the businesses, which appear without any signals from the global market. Moreover, there are many political wars, which have affected international business such as the US-China trade was. Therefore, many medium-sized enterprises (SMEs) have introduced into their business activities so called corporate social responsibility (CSR) practices, which would help the enterprises to leverage their business activities by taking into account the inside and outside shareholders such as workers, clients, creditors, business allies, trade unions, local governance, non-profit organizations (NGOs) and governments. Big body of research suggests that SMEs are losing the competition with the multinational firms in the acquiring of CSR policies and practices (cf. Brammer et al., 2012; Cassells \& Lewis, 2011; Revell et al., 2010). Similarly, a report from the European Union explicitly underlines this gap between SMEs and bigger firms. Based on the above statements SMEs are significant factor for the economic growth across the majorty of European states, that are engaged with sustainable growth (Klewitz \& Hansen, 2014; Revell 
et al., 2010). Moreover, it is of crucial weight to realize that SMEs' aspects of implementing a converging pattern to business. Other studies on corporate social sustainability suggest CSR steers to better corporate image, emerging sales and higher clients credibility, and higher efficiency and quality (Mishra \& Suar, 2010). CSR in the frame of big multinational enterprises leads to the company's setting of social accountability and social responsiveness, practices, and initiatives, which could boost its bonding with the local communities (Luo, 2006). Considering the economic prominence of SMEs and their increasing level of internationalization (for example, in the neighboring Austria more than $80 \%$ of the enterprises are SMEs and their level of internationalization is very high), this study intends to focus on the process of internationalization across selected Czech SMEs, their extent of CSR program adoption, organizational structure and models of management. We start with the notion that local communities impose particular demands on appropriate business policies and attitudes. Apart from business acumen for generating profit and higher margins, the paper argues the satisfaction of community's expectations is significantly critical for SMEs. CSR is more than a strategy, but at the same time outlines a firm assignment, which SMEs supposes to comply with the moral, social, ecological, and economic requirements from the local business partners in all markets where they are present. This positive image and broad stakeholder support can be a valuable extension of SMEs' resource bases that can be used to compete against larger firms that are less resource-constraint and ultimately influence SMEs performance (Fiala \& Hedija, 2019).

Evidently, the most influential aspect on SME endeavors is nested in the competences of the top management to make strategic decisions (Sommer, Durst, \& Haug, 2007, pp. 256). The senior management plays significant role in the process of internationalization, which have been research in previous studies on sustainability and top management teams (Velinov et al., 2020). European Union has investigated in the previously stated document that the most common issues in the process of SME internationalization are absence of envisaged strategy, lack of know-how on internationalization patterns, information asymmetries during searching corresponding allies and wrong forecasts on the market prospectus (Observatory of European SMEs 2003, pp. 35 et seqq.). In the context of internationalization, the resource scarcity of SMEs may impact on their ability to enter foreign markets and can also limit a smaller firm's ability to reach more advanced stages of internationalization (Westhead et al., 2001 and 2002). Other aspects are the experiences of managers regarding internationalization. Different studies mentioned the relevance of the managers' attitudes (CEDEFOP, 2002; Ajzen \& Fishbein, 1980; Ajzen \& Madden, 1986; Allport, 1935; Rosenberg \& Hovland, 1960).

There are numerous entities that maintain a "critical eye" on CSR. These relationships are critical for the firms to realize its mission in producing goods or services are often referred to as primary stakeholders and include: clients, inside managers and workers, governmental bodies, suppliers, and creditors. Secondary stakeholders are consisting of social and political participants functioning as supporters of the mission by assuring their tacit approval of the SME's activities, thereby making them acceptable and giving the business credibility. Such nonpriority stakeholders might be competitors, media, local communities, and non-governmental organizations (NGOs) (Maon et al., 2009). Based on the literature review, the paper aims to 
investigate the link between CSR practices and the level of internationalization, and the influence of independent stakeholders on SMEs foreign-market activities.

There are the following hypotheses in the paper:

Hypothesis 1: SMEs with CSR practices tend to have higher level of internationalization.

Hypothesis 2: Managers and employees play an important role in influencing CSR practices of SMEs in foreign markets.

Hypothesis 3: CSR practices of SMEs in foreign markets will have a positive impact on SMEs' performance.

\section{Methodology and Data Collection}

The study investigates more than 70 Czech SMEs from the transport and logistics sectors classified according to the EU classifications on SMEs. The data collection will be carried out from secondary information sources as SMEs annual reports, Eurostat, database Albertina, Bisnode and Thomson Reuters. Additionally, data on sustainability and FDIs will be collected directly from several of the SMEs because of the fact that specific information is required on their international business activities and corporate strategy. The paper aims at identifying the stakeholders and the specifics of small and medium business in Czechia, identifying the share of SMEs that have social responsibility practices in regard to environment, employees and society, systematizing the factors that impede the formation of corporate social responsibility of SMEs. Furthermore, the paper is assessing the level of corporate responsibility of SMEs in Czechia, analyzing the influence of employees of enterprises on the formation of corporate social responsibility, conducting a survey of employees of SMEs to determine the functioning elements of business social responsibility, studying Global practices in the implementation of corporate social responsibility. Moreover, the paper is developing a model of adaptation of individual elements of foreign corporate social responsibility for Czech small business, proposing a mechanism allowing SMEs to increase the efficiency of their activities through the implementation of corporate social responsibility practices, testing the results of research in the international scientific space (Velinov et al., 2020).

In order to establish the level of social responsibility in practice, empirical research was carried out in the form of a questionnaire survey. Nuts 2 Northeast Cohesion Region has been elected. It consists of Pardubice, Hradec Kralove and Liberec region. Medium-sized and large enterprises have been selected for research, given that the smaller the company, the more difficult it is to implement CSR both organizationally and staffed. The selected sector was Transport. This section covers passenger and freight transport activities, regular or irregular, on rails, by pipeline, by road, water or air, and related activities such as terminals, parking and storage facilities, terminals, etc. This section includes the rental of transport equipment with a driver or operator, as well as postal and courier activities.

Using the Magnus web and Albertina enterprise database (2017), it was found that there is a basic statistical set of 70 medium and large enterprises (with 50 or more employees), that are doing business in the Transport sector. The questionnaire was intended for a top management employee of a company who is expected to have comprehensive knowledge of 
about the enterprise. First and foremost, it was necessary to ensure representativeness. The representativeness of the sample for research can be statistically determined by the formula (1) (Kozel, 2006):

$$
n>\frac{t_{\alpha}^{2} * p *(1-p)}{d^{2}}
$$

where: $n$ the minimum selection range is required, $\alpha$ is reliability, $t \alpha$ indicates the coefficient of reliability for a given $\alpha, p$ is an estimate of the relative frequency of the character examined in the population, $d$ determines the required permissible error in the research. If the required reliability is selected $\alpha=0.1$, the coefficient of the confidence interval is $90 \%$ $\mathrm{t} \alpha=1.65$, with a permissible error $\mathrm{d}=10 \%$ with an estimate of the relative frequency $\mathrm{p}=0.9$, then according to the above, the minimum number of elements in the sample should reach at least 24 enterprises.

At the beginning of 2018, data collection took place and the return was $40 \%$, or 28 enterprises. No questionnaire was excluded from this file. This ensured the calculated representativeness. The evaluation of the questionnaire was carried out in IBM SPSS Statistics and MS Excel. The data are drawn from the original research of the co-author (Činčalová, 2018). Table 1 shows the basic statistics of this representative sample of the enterprises in transport sector, namely the variables number of employees in 2017 and turnover revenues for 2017.

Table 1: Descriptive statistics on the selected firms. Source: own elaboration

\begin{tabular}{|l|l|l|l|}
\hline \multicolumn{2}{|l|}{} & $\begin{array}{l}\text { Number of employees } \\
\text { in } \mathbf{2 0 1 7}\end{array}$ & Firm Turnover Revenue in 2017 \\
\hline N & Valid & 28 & 28 \\
\hline & Missing & 0 & 0 \\
\hline Mean & 172.75 & $361,995,235.86$ \\
\hline Median & 103.00 & $288,785,000.00$ \\
\hline Std. Deviation & 136.685 & $305,256,398.562$ \\
\hline Variance & $18,682.861$ & $93,181,468,862,993,200.000$ \\
\hline Skewness & 0.812 & 1.494 \\
\hline Std. Error of Skewness & 0.441 & 0.441 \\
\hline Kurtosis & -0.693 & 2.413 \\
\hline Std. Error of Kurtosis & 0.858 & 0.858 \\
\hline Range & 452 & $1,276,267,000$ \\
\hline Minimum & 30 & $51,818,000$ \\
\hline Maximum & 482 & $1,328,085,000$ \\
\hline Percentiles & 25 & 59.50 & $117,658,250.00$ \\
\hline & 103.00 & $288,785,000.00$ \\
\hline & 285.00 & $489,922,250.00$ \\
\hline
\end{tabular}

\section{Results}

The questionnaire was completed by representatives of companies with an average of 173 employees and a turnover of almost 362 million CZK, the median is 103 employees and CZK 289 million. Smallest business in the research sample had 30 employees and a turnover 
of CZK 51.8 million, on the contrary, the largest company employs 482 employees and has a turnover of CZK 1.33 billion.

\section{Discussion}

The questionnaire contained 9 questions of semi-open and closed questions concerning the use of CSR, the degree of interconnection of social responsibility with the corporate strategy, the activities carried out by enterprises under the 4 pillars, subsequent CSR measurement, CSR certification, as well as other areas.

The introductory question found that 21 of the companies examined $(75 \%$ of those surveyed) use the CSR concept, 4 companies do not use it, but are considering introducing it from this year or next.

Another question examined the importance of different motives for introducing social responsibility. Table 2 shows the basic characteristics (mean, standard deviation and error, confidence interval for average, minimum and maximum value) for all subquestions that have been rated by the Likert scale from 1 to 5 according to the importance of the theme

(1 - most important, 5 - unimportant).

Table 2: Descriptive statistics on motives for introducing CSR activities. Source: own elaboration.

\begin{tabular}{|c|c|c|c|c|c|c|c|}
\hline \multirow{2}{*}{ Subquestion } & \multirow{2}{*}{ Mean } & \multirow{2}{*}{ St.Dev. } & \multirow{2}{*}{$\begin{array}{l}\text { St.Error of } \\
\text { Skewness }\end{array}$} & \multicolumn{2}{|c|}{$95 \%$ Confidence interval } & \multirow{2}{*}{ Minimum } & \multirow{2}{*}{ Maximum } \\
\hline & & & & $\begin{array}{c}\text { Low } \\
\text { confidence }\end{array}$ & $\begin{array}{c}\text { High } \\
\text { confidence }\end{array}$ & & \\
\hline $\begin{array}{c}1-\text { convinced firms. } \\
\text { that it is correct }\end{array}$ & 1.750 & 0.4410 & 0.0833 & 1.579 & 1.921 & 1.0 & 2.0 \\
\hline $\begin{array}{c}2 \text { - effort on gaining } \\
\text { competitive } \\
\text { advantage }\end{array}$ & 2.393 & 0.9165 & 0.1732 & 2.037 & 2.748 & 1.0 & 5.0 \\
\hline $\begin{array}{l}3 \text { - profit increase. } \\
\text { costs decrease }\end{array}$ & 2.000 & 0.8165 & 0.1543 & 1.683 & 2.317 & 1.0 & 5.0 \\
\hline $\begin{array}{c}4-\text { increase of } \\
\text { loyality among } \\
\text { customers }\end{array}$ & 1.393 & 0.6853 & 0.1295 & 1.127 & 1.659 & 1.0 & 4.0 \\
\hline $\begin{array}{l}5 \text { - firm image } \\
\text { improvement }\end{array}$ & 1.286 & 0.4600 & 0.0869 & 1.107 & 1.464 & 1.0 & 2.0 \\
\hline 6 - public relations & 1.250 & 0.4410 & 0.0833 & 1.079 & 1.421 & 1.0 & 2.0 \\
\hline $\begin{array}{c}7 \text { - external forces } \\
\text { pressure }\end{array}$ & 3.500 & 1.1055 & 0.2089 & 3.071 & 3.929 & 2.0 & 5.0 \\
\hline $\begin{array}{c}8 \text { - engagement and } \\
\text { retention of skilled } \\
\text { employees }\end{array}$ & 2.000 & 1.2172 & 0.2300 & 1.528 & 2.472 & 1.0 & 4.0 \\
\hline $\begin{array}{l}9-\text { good looking in } \\
\text { the eyes of potential } \\
\text { investors }\end{array}$ & 1.679 & 1.0905 & 0.2061 & 1.256 & 2.101 & 1.0 & 5.0 \\
\hline Total & 1.917 & 1.0660 & 0.0672 & 1.784 & 2.049 & 1.0 & 5.0 \\
\hline
\end{tabular}

\section{Conclusions}

The following questions concerned the use of CSR activities within the pillars, their importance and measurement. It was found that all the undertakings examined reported at 
least one activity from each area and also measured them in these pillars, except for 6 enterprises that do not target to a philanthropic area. The social pillar is the most important of the 10 (see Table 3). It is clear from Table 3 that 18 undertakings see differences between the pillars. The other 10 companies indicated that all pillars are equally important and it is not possible to say which or less.

Table 3: Importance of the CSR pillars. Source: own elaboration.

\begin{tabular}{|c|c|c|}
\hline Pillar/importance & $\begin{array}{c}\text { The most } \\
\text { important }\end{array}$ & The least important \\
\hline Economical & 5 & 5 \\
\hline Social & 10 & 0 \\
\hline Environmental & 3 & 8 \\
\hline Philanthropic & 0 & 5 \\
\hline Total & 18 & 18 \\
\hline
\end{tabular}

There are a large number of transport companies and it is difficult for them to increase their market share. They often enter into short-term contracts, also because they offer similar services and compete mainly with price. Potential new comers have easy access to distribution channels, and with more and more opportunities and no need for high initial capital, there are almost no barriers to entry.

Suppliers' bargaining power depends on fuel price, policy, taxes, land price and others. Input prices have a big share of how profitable the business is. The bargaining power of customers is related to the number of current competitors in the sector - there is a large selection of them, customers can easily compare the prices of the services provided and in some cases vertical integration with producers takes place. The availability of substitutes is high (e.g. rail, air transport), but it depends on the nature of the goods transported (the difference in whether bricks or perishable goods are transported).

\section{References}

Bashtovaya, V. (2014). CSR reporting in the United States and Russia. Social Responsibility Journal, 10(1), 68-84. https://doi.org/10.1108/SRJ-11-2012-0150

Belyaeva, Z. (2018). Business Environment Challenges and Trends for Contemporary SMEs in Europe. In The Sustainable Marketing Concept in European SMEs: Insights from the Food E Drink Industry (pp. 13-28). Emerald Publishing Limited.

Brammer, S., Jackson, G., \& Matten, D. (2012). Corporate social responsibility and institutional theory: New perspectives on private governance. Socio-Economic Review, 10(1), 3-28. https://doi.org/10.1093/ser/mwr030

Činčalová, S. (2018). Evaluation of the Current Position of CSR in the Logistics Sector. In Innovation Management, Entrepreneurship and Sustainability (IMES 2018) (pp. 154-165). Vysoká škola ekonomická v Praze.

Fiala, R. \& Hedija, V. (2019). Testing the validity of Gibrat's law in the context of profitability performance. Economic Research-Ekonomska Istraživanja, 32(1), 28502863. https://doi.org/10.1080/1331677X.2019.1655656

Hassid, J. (2002). Internationalisation and Changing Skills Needs in European Small Firms: Synthesis Report. CEDEFOP Reference Series. Bernan Associates, 4611-F Assembly Drive, Lanham, MD 20706-4391

Klewitz, J., \& Hansen, E. G. (2014). Sustainability-oriented innovation of SMEs: a systematic review. Journal of Cleaner Production, 65, 57-75. https://doi.org/10.1016/j.jclepro.2013.07.017

Luo, Y. (2006). Political behavior, social responsibility, and perceived corruption: A structuration perspective. Journal of International Business Studies, 37, 747-766. https://doi.org/10.1057/palgrave.jibs.8400224 
Maon, F., Lindgreen, A., \& Swaen, V. (2009). Designing and implementing corporate social responsibility: An integrative framework grounded in theory and practice, Journal of Business Ethics, 87, 71-89. https://doi.org/10.1007/s10551-008-9804-2

Mishra, S., \& Suar, D. (2010). Does corporate social responsibility influence firm performance of Indian companies? Journal of Business Ethics, 95, 571-601. https://doi.org/10.1007/s10551-010-0441-1

Przytuła, S., Formánková, S., Ubrežiová, I., \& Dunay, A. (2019). Corporate Social Responsibility in Visegrad Countries (Poland, Czech Republic, Slovakia, Hungary) Overall Landscape. In Corporate Social Responsibility in Poland (pp. 325-353). Springer, Cham.

Sommer, L., Durst, S., \& Haug, M. (2007). The role of the international Owner-Manager Identity in the Internationalization Process of SME. The Business Review, 9(1), 256-265.

Uzhegova, M., Torkkeli, L., \& Ivanova-Gongne, M. (2019). The Role of Culture in Responsible Business Practice: An Exploration of Finnish and Russian SMEs. In The Changing Strategies of International Business (pp. 177197). Palgrave Macmillan, Cham.

Velinov, E., Maly, M., Petrenko, Y., Denisov, I., \& Vassilev, V. (2020). The Role of Top Management Team Digitalization and Firm Internationalization for Sustainable Business. Sustainability, 12(22), 9502. https://doi.org/10.3390/su12229502

Velinov, E., Vassilev, V., \& Denisov, I. (2018). Holacracy and Obliquity: contingency management approaches in organizing companies. Problems and Perspectives in Management, 16(1), 330-335. https://doi.org/10.21511/ppm.16(1).2018.32

Westhead, P., Binks, M., Ucbasaran, D., \& Wright, M. (2002). Internationalization of SMEs: A research note. Journal of Small Business and Enterprise Development, 9(1), 38-48. https://doi.org/10.1108/14626000210419473 